\title{
A New $\beta$-Lapachone Derivative from Distictella elongata (Vahl) Urb.
}

\author{
Erdal Bedir, ${ }^{a}$ Ana M. S. Pereira, ${ }^{* b}$, Shabana I. Khan, ${ }^{c}$ Amar Chittiboyina, ${ }^{e}$ \\ Rita M. Moraes ${ }^{c}$ and Ikhlas A. Khan ${ }^{c, d}$ \\ ${ }^{a}$ Department of Bioengineering, Faculty of Engineering, Ege University, Bornova, Izmir, 35100 Turkey \\ ${ }^{b}$ Departamento de Biotecnologia, Universidade de Ribeirão Preto, 14096-900 Ribeirão Preto-SP, Brazil \\ ${ }^{c}$ National Center for Natural Products Research, Research Institute of Pharmaceutical Sciences; \\ ${ }^{d}$ Department of Pharmacognosy, School of Pharmacy and ${ }^{e}$ Department of Medicinal Chemistry, School of Pharmacy, \\ University of Mississippi, University, MS 38677
}

\begin{abstract}
O presente trabalho descreve a elucidação estrutural de uma nova $\beta$-lapachona tipo naftoquinona, isolada a partir das raízes de Distictella elongata. A nova substância, apresentando fórmula molecular $\mathrm{C}_{16} \mathrm{H}_{16} \mathrm{O}_{6}$, foi identificada como sendo 4,7-diidróxi-10-metóxi-2,2-dimetil3,4-diidro-2H-benzo[h]cromeno-5,6-diona, de acordo com os dados obtidos por meio de análises espectrométricas. A elucidação estrutural foi realizada utilizando-se as técnicas espectrométricas [HRESIMS, 1D RMN $\left({ }^{1} \mathrm{H} \mathrm{e}{ }^{13} \mathrm{C}\right)$ e 2D RMN (g-DQF-COSY, g-HMQC e g-HMBC]. O extrato clorofórmico das raízes de $D$. elongata demonstrou significante inibição no crescimento de células do tipo SK-MEL (melanoma) e SK-OV-3 (carcinoma de ovário), com valores de $\mathrm{IC}_{50}$ de $40 \mu \mathrm{g} \mathrm{mL}^{-1}$ e $56 \mu \mathrm{g} \mathrm{mL}^{-1}$, respectivamente. Entretanto, a naftoquinona não foi responsável pela atividade citotóxica exibida pelo extrato.
\end{abstract}

The present study describes the structure elucidation of the new $\beta$-lapachone type naphthoquinone isolated from the roots of Distictella elongata. Its structure, according to the molecular formula $\mathrm{C}_{16} \mathrm{H}_{16} \mathrm{O}_{6}$, was identified as 4,7-dihydroxy-10-methoxy-2,2-dimethyl-3,4dihydro-2H-benzo[h]chromene-5,6-dione. The structure was assigned by spectrometric methods [HRESIMS, 1D NMR $\left({ }^{1} \mathrm{H}\right.$ and $\left.{ }^{13} \mathrm{C}\right)$, and 2D NMR (g-DQF-COSY, g-HMQC and g-HMBC]. Root chloroform extract of $D$. elongata showed significant inhibition of the growth of SK-MEL (melanoma) and SK-OV-3 (ovary adenocarcinoma) cells with $\mathrm{IC}_{50}$ values of $40 \mu \mathrm{g} \mathrm{mL}^{-1}$ and $56 \mu \mathrm{g} \mathrm{mL}{ }^{-1}$, respectively. However, the naphthoquinone was not responsible for the cytotoxic activity exhibited by the extract.

Keywords: cerrado, naphthoquinone, Bignoniaceae, Distictella elongata

\section{Introduction}

Many Bignoniaceae species have been investigated for their medicinal value. ${ }^{1}$ The anti-cancer activity of some endemic Bignoniaceae, native from Cerrado regions, like Tabebuia avellanedae, Anemopaegma arvense; Zeyheria montana, Kigelia pinnata and Jacaranda caucana have been reported in the literature..$^{2-6}$ The Bignoniaceae family, represented by more than 100 genera and about 800 species, including Distictella elongata, is mainly tropical, with most accessions dispersed in tropical America. ${ }^{7}$ This species occurs in Cerrado areas, within the states of Goiás,

*e-mail: apereira@unaerp.br
São Paulo and Minas Gerais. ${ }^{8}$ The Cerrado is a highly endangered ecosystem, due to the intensive introduction of soybean farming and cattle ranching in this area over the last two or three decades. It represents the second largest biome in South America after the rain forests and originally covered one fourth of Brazil. No phytochemical or pharmacological investigation has yet been carried out on D. elongata.

\section{Results and Discussion}

Fractionation of chloroform root extract from $D$. elongata resulted in the isolation of a new naphthoquinone (1). Compound $\mathbf{1}$ was obtained as reddish oil. The molecular 
formula of $\mathbf{1}$ was determined as $\mathrm{C}_{16} \mathrm{H}_{16} \mathrm{O}_{6}$ by HRESIMS, which exhibited ions at $\mathrm{m} / z 305.1031[\mathrm{M}+\mathrm{H}]^{+}$and 327.0846 $[\mathrm{M}+\mathrm{Na}]^{+}$(in the positive-ion mode).

The ${ }^{1} \mathrm{H}$ NMR $\left(\mathrm{CDCl}_{3}\right)$ spectrum of $\mathbf{1}$ exhibited a deshielded hydrogen at $\delta 12.7(\mathrm{~s}, O-\mathrm{H})$, two aromatic hydrogens overlapping at $\delta 7.29$, an $O$-methyl at $\delta 3.97$ $(s, 3 \mathrm{H})$, as well as a triplet at $\delta 4.96(\mathrm{t}, J 6.0 \mathrm{~Hz})$. In addition, the ${ }^{1} \mathrm{H}$ NMR spectrum showed two tertiary methyl hydrogens at $\delta 1.45$ and $\delta 1.55$, and a gem-methylene signals at $\delta 2.05$ and $\delta 2.12$ (dd, $J 6.0$ and $14.2 \mathrm{~Hz}, 2 \mathrm{H}$ ). The ${ }^{13} \mathrm{C}$ NMR spectrum displayed 16 signals including six aromatic, two olefinic and two carbonyl signals. Total 6 double bonds, attributable to aforementioned carbon signals, when considered with 9 unsaturation degrees, the remaining 3 degrees required that compound $\mathbf{1}$ consists of tri-ring systems. The presence of $\beta$-lapachone type pyranonaphthoquinone skeleton (compound $\mathbf{1}$ ), which is common in Bignoniaceae family, was easily deduced from the proton and carbon chemical shifts. ${ }^{9-11}$

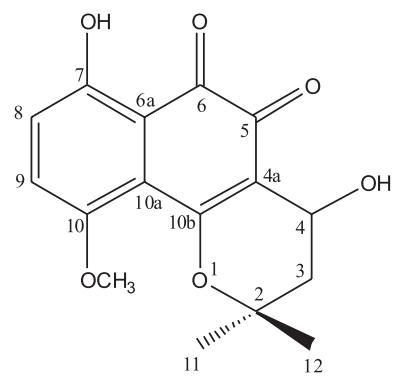

Figure 1. Structure of new naphthoquinone, compound 1.

Two overlapping aromatic hydrogens $(7.29,2 \mathrm{H})$ did not provide any information about substitution pattern of the aromatic ring. Thus, the ${ }^{1} \mathrm{H}$ NMR spectrum of compound 1 was obtained using acetone- $d_{6}$ as a solvent, in which aromatic hydrogens were observed as doublets at $\delta 7.52$ $(\mathrm{d}, 9.0 \mathrm{~Hz}, 1 \mathrm{H})$, and $\delta 7.30(\mathrm{~d}, 9.0 \mathrm{~Hz}, 1 \mathrm{H})$, indicative of the presence of ortho-coupling hydrogens.

The combined use of g-DQF-COSY, g-HMQC and $\mathrm{g}-\mathrm{HMBC}$ techniques permitted the complete assignment


$$
\text { (R)-4-hydroxy- } \beta \text {-lapachone } 1
$$

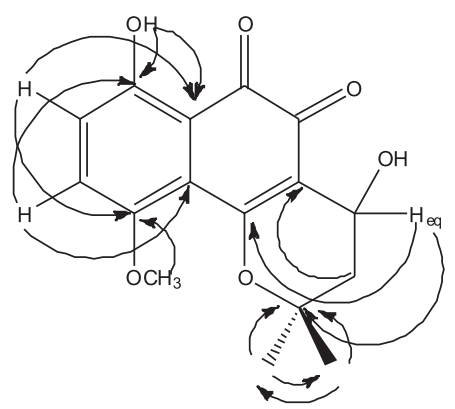

Figure 2. Key HMBC of compound $\mathbf{1}$.

of the pyranonaphthoquinone skeleton and the substitution pattern for the compound $\mathbf{1}$. Thus, the deshielded ${ }^{1} \mathrm{H}$ NMR signal at $\delta 12.7[\mathrm{C}-7(\mathrm{OH})]$ showed correlations with a methine carbon at $\delta 127.9$ and two quaternary carbons at $\delta 156.6$ and $\delta 114.1$, attributed to C-8, C-7 and C-6a, respectively. Also, a methine carbon at $\delta 127.9(\mathrm{C}-8)$ showed correlation with the aromatic hydrogen at $\delta 7.30$ (d, $9.0 \mathrm{~Hz}$, in acetone- $d_{6}$ ), which is assigned to H-8. The aromatic hydrogen observed at $\delta 7.52$ (in acetone- $d_{6}, \mathrm{H}-9$ ) indicated a long-range correlation in the G-HMBC spectrum with a quaternary carbon at $\delta 117.5$, attributed to C-10a. The carbon signal at $\delta 155.1$ displayed a correlation with $O$-methyl hydrogen $(\delta 3.97, \mathrm{~s})$ in the g-HMBC spectrum, hence allowing it to be assigned unambiguously to C-10, and locating the methoxyl group to C-10. Moreover, the position of the hydroxyl group located on pyrane ring was deduced from $\mathrm{g}$-HMBC correlations from quaternary carbons C-10b (155.9) and C-2 (80.4) to a methine proton at $\delta 4.96(t, J 6.0 \mathrm{~Hz})$ attributed to $\mathrm{H}-4$.

Based on these results, the structure of 1 , a new natural product, was established as 4,7-dihydroxy-10-methoxy2,2-dimethyl-3,4-dihydro-2H-benzo[h]chromene-5,6dione. Having established the structure of $\mathbf{1}$, the relative stereochemistry of chiral center (C-4) remained to be solved. The absolute stereochemistry of $\mathbf{1}$ was established by NMR data and molecular modeling analysis after calculation of the minimal conformational energy for each of the two possible enantiomers using Accelrys Discovery Studio v2.0.0.7264. Only the stereoisomer, $(S)$-4-hydroxy

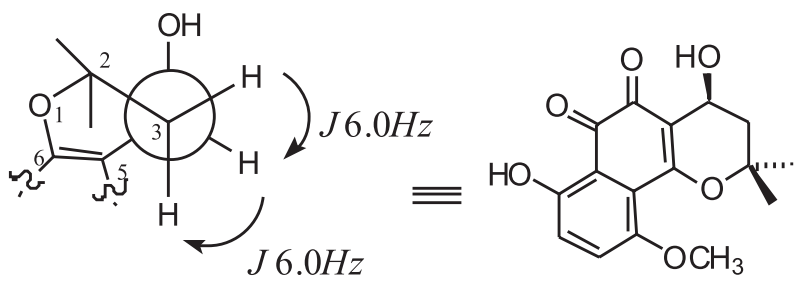

(S)-4-hydroxy- $\beta$-lapachone 1

Figure 3. Stereo conformers of 4-hydroxy- $\beta$-lapachone $\mathbf{1}$. 
isomer of $\mathbf{1}$ showed agreement with the coupling constants observed in the ${ }^{1} \mathrm{H}$ NMR spectrum and the dihedral angles measured after the calculation of the minimal conformation energy for each of the two possible stereoisomers. The key coupling constant analyzed was that measured between $\mathrm{H} 3 \mathrm{a}-\mathrm{H} 4=\mathrm{H} 3 \mathrm{~b}-\mathrm{H} 4=6.0 \mathrm{~Hz}$. Therefore, the dihedral angles H3a-C3-C4-H4 and H3b-C3-C4-H4 must be identical. Whereas, the dihedral angles for the $R$-isomer should be non identical and should have at least two different coupling constants. When a comparison was made of the current analysis data with reported spectral data of similar systems, ${ }^{12,13}$ we concluded that the absolute stereochemistry at C-4 position must be in $S$ configuration.

The chloroform root extract of $D$. elongata was tested for in vitro growth inhibition activity against a panel of four cancer cell lines. Results included in Table 1 showed that the extract significantly inhibited the growth of SK-MEL and SK-OV-3 cells with $\mathrm{IC}_{50}$ values of $40 \mu \mathrm{g} \mathrm{mL}^{-1}$ and $56 \mu \mathrm{g} \mathrm{mL}^{-1}$, respectively. However, 4,7-dihydroxy-10-methoxy-2,2dimethyl-3,4-dihydro-2H-benzo[h]-chromene-5,6-dione (1) was not responsible for the anticancer activity exhibited by the whole extracts (Table 1).

Table 1. In vitro anticancer activity of Distictella elongata root extract and compound 1

\begin{tabular}{lcccc}
\hline Sample name & \multicolumn{4}{c}{$\mathrm{IC}_{50} /\left(\mu \mathrm{g} \mathrm{mL}^{-1}\right)$} \\
\cline { 2 - 5 } & SK-MEL & $\mathrm{KB}$ & $\mathrm{BT}-549$ & $\mathrm{SK}-\mathrm{OV}-3$ \\
\hline D. elongata root extract & 40 & $>100$ & $>100$ & 56 \\
1 & $\mathrm{NA}$ & $>10$ & $\mathrm{NA}$ & $\mathrm{NA}$ \\
\hline
\end{tabular}

The highest concentration tested was $100 \mu \mathrm{g} \mathrm{mL}{ }^{-1}$ and $10 \mu \mathrm{g} \mathrm{mL}-1$ for extract and for $\mathbf{1}$, respectively. $\mathrm{IC}_{50}=$ concentration that inhibits cell growth by $50 \%$; $\mathrm{NA}=$ not active.

\section{Experimental}

\section{General}

NMR spectra were recorded on a Bruker ${ }^{\circledR}$ Avance DRX $500 \mathrm{FT}$ spectrometer operating at 500 and $125 \mathrm{MHz}$ for ${ }^{1} \mathrm{H}$ and ${ }^{13} \mathrm{C}$ NMR, respectively. The chemical shift values are reported as parts per million (ppm) units relative to tetramethylsilane (TMS); and the coupling constants are in $\mathrm{Hz}$ (in parentheses). For the ${ }^{13} \mathrm{C}$ NMR spectra, multiplicities were determined by a distortionless enhancement by polarization transfer (DEPT) experiment. HRESIMS (High Resolution Electrospray Ionization Mass Spectrometry) were obtained using a Bruker BioApex FT-MS in ESI mode. For TLC, precoated Si 250F layers (Baker) were used. Column chromatography was performed on silica gel 230-400 mesh (Merck).

\section{Plant material}

Roots of Distictella elongata (Bignoniaceae) were collected from preserved areas of a Brazilian Cerrado, at the Biological Reserve of Mogi-Guaçu Ecological and Experimental Station, São Paulo, Brazil. A voucher specimen was deposited in the herbarium of the University of Ribeirão Preto (HPM-482). The roots were dried at $50{ }^{\circ} \mathrm{C}$, powdered and kept until ready for extraction.

\section{Extraction and isolation}

Powdered roots $(330 \mathrm{~g})$ were extracted in $\mathrm{CHCl}_{3}$ for 7 days. The $\mathrm{CHCl}_{3}$ extract was concentrated to a small volume at reduced pressure to yield $1.3 \mathrm{~g}$ of oily residue. This residue was fractionated on a silica gel column eluting with hexane, and hexane/ethyl acetate gradient elution to ethyl acetate $100 \%$. Using 50\% hexane/ethyl acetate solvent a red crystal was obtained (naphthoquinone) and further purified by preparative TLC using ethyl acetate/hexane (4:1) as solvent system. The amount of $30 \mathrm{mg}$ of the naphthoquinone was removed from the layer. The final purification performed on Sephadex column (LH-20, $30 \mathrm{mg}$ ) eluted with $\mathrm{MeOH}$, to afford $9 \mathrm{mg}$ naphthoquinone $\mathbf{1}$.

\section{Biological activity}

The in vitro anticancer activity was tested against a panel of four human cancer cell lines that included SK-MEL (malignant, melanoma), KB (epidermal carcinoma, oral), BT-549 (ductal carcinoma, breast), and SK-OV-3 (ovary carcinoma). ${ }^{14}$ All the cell lines were from ATCC (Manassas, VA). The cells were cultured in $75 \mathrm{~cm}^{2}$ culture flasks in RPMI1640 medium ( $\mathrm{Gibco}^{\mathrm{TM}}$, Invitrogen Corp.) supplemented with bovine calf serum $(10 \%)$ and amikacin $\left(60 \mathrm{mg} \mathrm{L}^{-1}\right)$, at $37^{\circ} \mathrm{C}$, $95 \%$ humidity, $5 \% \mathrm{CO}_{2}$ using standard cell culture techniques. The assay was performed in 96-well microplates. Cells were seeded to the wells of the plate at a density of 25,000 cells/ well and grown for 24 hours at $37{ }^{\circ} \mathrm{C}$. Samples were added to the cells and again incubated for $48 \mathrm{~h}$. The number of viable cells was determined according to Neutral Red assay procedure. ${ }^{15} \mathrm{IC}_{50}$ (the concentration of the test sample that caused a growth inhibition of 50\% after $48 \mathrm{~h}$ exposure of the cells) was calculated from the dose curves generated by plotting percent growth versus the test concentration on a logarithmic scale using Microsoft Excel®.

\section{Compound 1}

Reddish oil; ${ }^{1} \mathrm{H}$ NMR data (500 MHz, $\mathrm{CDCl}_{3}$ ): $\delta 12.7$ (1H, s, OH-7), 7.29 (s, 2H, overlapping), $4.96(1 \mathrm{H}, \mathrm{t}, J$ $6.0 \mathrm{~Hz}, \mathrm{H}-4), 3.97$ (3H, s, O-CH $\left.{ }_{3}\right), 2.12(1 \mathrm{H}, \mathrm{dd}, J 6.0$ and 
$14.2 \mathrm{~Hz}, \mathrm{H}-3 \mathrm{a}), 2.05$ (1H, dd, J 6.0 and $14.2 \mathrm{~Hz}, \mathrm{H}-3 \mathrm{~b})$, 1.55 (3H, s, Me-12), 1.45 (3H, s, Me-11); ${ }^{1} \mathrm{H}$ NMR data (500 MHz, acetone- $\left.d_{6}\right): \delta 12.8(1 \mathrm{H}, \mathrm{s}, \mathrm{OH}-7), 7.52(1 \mathrm{H}, \mathrm{d}$, $J 9.0 \mathrm{~Hz}, \mathrm{H}-9), 7.30$ (1H, d, J $9.0 \mathrm{~Hz}, \mathrm{H}-8), 4.93$ (1H, d, J $5.0 \mathrm{~Hz}, \mathrm{H}-4), 2.31$ (1H, dd, J 5.0 and $14.0 \mathrm{~Hz}, \mathrm{H}-3 \mathrm{a}), 2.26$ (1H, dd, J 5.0 and 14.0 Hz, H-3b), 1.51 (3H, s, Me-12), 1.46 $(3 \mathrm{H}, \mathrm{s}, \mathrm{Me}-11) .{ }^{13} \mathrm{C} \mathrm{NMR}$ data $\left(125 \mathrm{MHz}, \mathrm{CDCl}_{3}\right): \delta 191.4$ (C-6), 177.9 (C-5), 156.6 (C-7), 155.9 (C-10b), 155.1 (C10), 127.9 (C-8), 123.1 (C-9), 118.6 (C-4a), 117.5 (C-10a), 114.1 (C-6a), 80.4 (C-2), 60.0 (C-4), 56,2 (O-CH $)_{3}, 39.9$ (C-3), 27.3 (x2, Me-11 and Me-12); HRESIFTMS: $m / z$ $305.1031[\mathrm{M}+\mathrm{H}]^{+}$(calculated for $\left.\mathrm{C}_{16} \mathrm{H}_{16} \mathrm{O}_{6}: 305.1026\right)$.

\section{Acknowledgments}

This work was supported in part by the United States Department of Agriculture, ARS Specific Cooperative Research Agreement and by the FAPESP BIOTA project No. 99/10610-1.

\section{References}

1. Gentry, A. H.; Ann. Missouri Bot. Gard. 1992, 79, 53.

2. de Santana, C. F.; de Lima, O.; d' Albuquerque, I. L.; Lacerda, A. L.; Martins, D. G.; Rev. Inst. Antibiot. 1968, 8, 89.

3. Ogura, M.; Cordell, G. A.; Farnsworth, R.; Lloydia 1977, 40, 157.

4. Jácome, R. L. R. P.; Oliveira, A. B. ; Raslan, D. S.; Muller, A.; Wagner, H. Quim. Nova 1999, 22, 175.
5. Jackson, S. J.; Houghton, P. J.; Retsas, S.; Photiou, A.; Planta Med. 2000, 66, 758.

6. Uchino, T.; Kawahara, N.; Sekita, S.; Satake, M.; Saito, Y.; Tokunaga, H.; Ando, M.; Toxicol. In Vitro 2004, 18, 255.

7. Cronquist, A.; An Integrated System of Classification of Flowering Plant; Columbia University Press: New York, 1981.

8. Scudeller, V. V.; Carvalho-Okano, R. M. de; Iheringia-Série Botânica 1998, 51, 79.

9. McDonald, I. A.; Simpson, J. T.; Sirekowski, A. F.; Aust. J. Chem. 1977, 30, 1727.

10. Oliveira, A. B.; Raslan, D. S.; Miraglia, M. C. M.; Mesquita, A. A. L.; Quim. Nova 1990, 13, 302.

11. Schaffner-Sabba, K.; Schmidt-Ruppin, K. H.; Wehrli, W.; Schuerch, A. R.; Wasley, J. W. F.; J. Med. Chem. 1984, 27, 990.

12. Burgard, A.; Lang, H.-J.; Gerlach, U.; Tetrahedron 1999, 55, 7555.

13. Yamada, T.; Nagata, T.; Sugi, K. D.; Yorozu, K.; Ikeno, T.; Ohtsuka, Y.; Miyazaki, D.; Mukaiyama, T.; Chem. Eur. J. 2003, 9, 4485 .

14. Mustafa, J.; Khan, S. I.; Ma, G.; Walker, L. A.; Khan, I. A.; Lipids 2004, 39, 659.

15. Borenfreund, E.; Babich, H.; Martin-Alguacil, N.; Toxicol. In Vitro $1988,1,1$.

Received: October 19, 2007

Web Release Date: December 18, 2008

FAPESP helped in meeting the publication costs of this article. 